\title{
Joachim Ringelnatz's Parody of the Little Red Ridding Hood as an Anti-nationalist Response to the Brothers Grimm
}

\author{
Maxim Duleba ${ }^{1, *}$ \\ ${ }^{I}$ Department of German, Dutch and Scandinavian Studies, Faculty of Arts, Comenius University in Bratislava, \\ Slovak Republic \\ ${ }^{*}$ Corresponding author. Email: duleba2@uniba.sk
}

\begin{abstract}
The article focuses on the most famous "fairy tale" of a popular German poet Joachim Ringelnatz, Kuttel Daddeldu Tells His Children the Fairy Tale About Little Red Cap (1923) and complements preceding scholarly discourse on the tales' highly unconventional and subversive character by interpreting its' anti-ideological and anti-nationalist dimension. Despite the fact of the tale being a parody of Brothers Grimms' famous Little Red Riding Hood narrative (1812, 1819, 1857), only Craig Monk (1998) interpreted Ringelnatz's text in relation to the Jacob Grimm's and Wilhelm Grimm's notions, whereas other interpreters (Pape, Zipe, Detken) explicated the fairy tales' unchildlike character as its dominant feature. By juxtaposing tales' "unchildlike character" with Grimm's romantic, nationalist and idealistic conceptualization of the folktales' "childlike purity" as originating from the morally ideal "Golden Age" of nations beginning, the text is explicated as an anti-nationalist response to nationalistic conceptualizations of the "folktale" within the Weimar period (1918 - 1933).
\end{abstract}

Keywords: Joachim Ringelnatz, Brothers Grimm, Little Red-Cap, Fairy tale genre, Fairy tale parody, Folktale, Nationalism, The critique of ideology.

\section{INTRODUCTION}

In 1923, German author Joachim Ringelnatz (Hans Gustav Bötticher, 1883-1934), whose grotesque poetry remains highly popular even nowadays, published a parodic variation of Brothers Grimm's Little Red Riding Hood (1812, 1819 , 1857). Considering that adaptation and transformation of enormously popular and rules of the fairy tale genre setting Grimm's tales have been dominant tendencies of fairy tale writing of Weimar (interwar) period [1], Ringelnatz's choice of the renowned tale as of a parodied referent does not strike as surprising. However, it is the highly nonconventional and (even for a parody) provocative character of Ringelnatz's transformation that raises intriguing questions about the potential triggers of his subversive aesthetic deed.

Kuttel Daddeldu Tells His Children the Fairy Tale About Little Red Cap turns upside down various conventions of a "classic", child-oriented modern fairy tale. Instead of a customary positive ending that surmounts suffering and opens doors for a utopic harmony (In 1930, an influential philosopher Ernst Bloch reductively but conventionally remarked that "the fairy tale narrates a wish-fulfilment" [2]), Ringelnatz's tale encloses with a disharmonic annihilation. The wolf, RedCap and the hunter end up swallowed by the grandmother. The expectations of a hypothetical child-reader are not only disregarded by such shockingly disharmonic ending, but also by the disrespectful tone in which the tales' narrator addresses his textual children audience: "So kids, if you can keep your mouths shut for just five minutes (...)"; "Old Captain Muckelmann told it to me [the tale] long ago when I was still little and stupid like you are now" [3]; "March yourselves out of here! Let your father pour one down the hatch now, you leftover small fry!" [3]. In addition to the insolence to child audience, the tales' explicit eroticism too does not comply with the conventional immaculacy of the child-oriented fairy tales. Not only that Red- 
Cap is sexualised as a "beautiful, wonderful, fine lass" with "very thick" "legs" [3] but we also encounter a sexual indication comprehensible only to the adult reader: "Well — and what does it matter to us what the two of them [the hunter and Red-Cap] wanted to do there deep in the woods since it had become very dark in the meantime" [3]. Following study interprets Ringelnatz's impudence to his hypothetical child-reader as a consequence of his relating to the parodied referent (Brothers Grimm's text).

\section{PRECEDING DISCOURSE}

Ringelnatz's insolence to his child audience has been a concern for most of the tales' interpreters. In the only ever written Ringelnatz-monography (1974) Walter Pape provides a biographical and psychological explanation. According to Pape, the destruction of the original text represents for Ringelnatz a parodic destruction of his own childhood, which has been influenced by the Grimm's tales, his life-long object of admiration. As a parodic self-relation, the tale corresponds with the overall dominant method of Ringelnatz's writing an inclination to self-parody [4].

In his monography on the variations of the Little Red Riding Hood narrative (1993), Jack Zipes contextualizes the tale with other fairy tales of the period and explicates it as an attempt "to smash the conservative expectations of the readers" and "to criticize" the "notion that children were soft, lovable creatures to be protected at all costs" [5]. Whether written by the left-wing authors, who educated their children audience toward the utopic future, or by the right-wing writers, whose tales affirmed utopic and conservative ideals, the moral didacticism and utopic character have greatly determined the shape of a Weimar period fairy tale. Ringelnatz's tale is than an anti-utopic counter-tale: Instead of confirming to the "child-protective" fairy-tale utopia, its' destructive harshness provides "a sober perspective on harsh realities in Germany" [5].

In her essay on the unchildlike nature of Ringelnatz's "children's literature" (2000), Antke Detken affirms Zipes' evaluation [6]. Inquiring whether Ringelnatz's Little Red Riding Hood is oriented at the children or adult audience, Detken comes to conclusion that both groups of readers are addressed simultaneously, as in both groups, the texts' elements undergo disparate arrangement [6]
In contrast to the other interpreters, Craig Monk in his monography on the Little Red Riding Hood in parodies (1998) does not explicate the tales "unchildlike nature". Monk also differs from other interpreters by putting an analytical emphasis on the tales' relation to its parodied referent [7]. Ringelnatz alludes to Wilhelm Grimm's and Jacob Grimm's claim that their tales have been collected from various sources and their folklorist "authenticity" remained intact and uncontaminated with their own authorial intentions. Ringelnatz alludes this posit of Brothers Grimm by making his narrator present the tale to his audience as being appropriated from someone else (from the "Old Captain Muckelmann") and therefore undoubtedly "authentic" ("Old Captain Muckelmann told it to me (...). And Captain Muckelmann never lied." [3]). However, despite of being taken from an external source, the tale "appropriated" by Ringelnatz's narrator fully corresponds with his interests, his disregard for children and his inclination to drinking. By appropriated tale being fully directed by narrators' interests, Ringelnatz questions the Brothers Grimm's claim of a folkloric "authenticity" by showing that noncontaminated, "authentic" versions of "folk" narratives are not possible, as "ideological and situational content invested in a tale through its authorship always remains present within the act of storytelling" [7].

These observations provide valuable insights into the texts' genre-conventions breaking character. However, apart from C. Monk, none of the interpreters approached tales' nonconventionality as constituted by Ringelnatz's dialogical act of responding to the nature of the parodied referent. C. Monk illustrates Ringelnatz's aesthetic relation to Grimm Brothers as a "relativisation" of their "authority" [7] in terms of their folkloric authenticity but does not inquire the tale as a reaction to that what the parodied referent represents with itself on a more ideological (nationalist) level.

By contextualizing two factors which previous interpretations treated as being separate from each other - the fact of Ringelnatz's insolence to his child reader (Pape, Zipes, Detken) and the fact of Ringelnatz's relation to (and undermining authority of) the Brothers Grimm (Monk), the tale opens itself to be understood not only as a psychological self-relation (Pape) and implicit experimentational commentary on the folktale and fairy tale genres (Zipes, Detken, Monk), but becomes comprehended also on a more anti/ideological level — as a manifestation of Ringelnatz's descent on the 
romantic nationalism of Brothers Grimm, in which the fairy-tales' "childlike purity" represents an idealistic link to the morally flawless and religiously utopic past-time of nations' beginning.

\section{JOACHIM RINGELNATZ'S PARODY OF THE LITTLE RED RIDDING HOOD AS AN ANTI- NATIONALIST RESPONSE TO THE GRIMM BROTHERS}

Even though Kinder- und Hausmärchen (Children's and Household Tales, 1819) significantly determined the future of children's literature, including those of Weimar period [8], Grimm Brothers themselves did not intend to target the children audience deliberately [9]. Their extensive editing of their collected tales, elimination of explicit erotic elements and adding of Christian symbolism, as well as their modification of the tales' narratives to succumb to the conservative patriarchal societal norms [10] has not been done with the juvenile but with an adult reader in mind, as Grimms strained to endorse their romantic "ideal notion of pure, natural German culture" [10] and to cultivate the "patriotic spirit of the German nation" [9] by appealing to an "adult yearning for an identification with the golden age of the innocent past (the "childhood" of the nation" [9]). Because of their conservative reconfiguration, the tales of Kinder- und Hausmärchen exhibit "child-like" qualities of "innocence" and "purity", which make them into a relative and in the past highly disputed extent [7] appropriate for the juvenile reader.

However, the Brothers Grimm's conceptualization of "childishness" is far from being "childish". In the earlier preface to folktales written by Wilhem Grimm, we read that "the poetry of the simple naïve life ["folktales"]", "possess the same purity as we see it reflected in the souls and eyes of children; they are simple, (...)" [qtd. in 9]. This childlike "purity" reflects for W. Grimm "an animated nature of a golden age" [qtd. in 9], of a utopic past-time in which man lived in a "childishly" uncorrupted religious oneness with God and nature; a past-time of primeval, uncorrupted roots ("childhood") from which the "nation" originated [9]. Overall, when Brothers Grimm "spoke about the child, they usually thought of it not so much in realistic terms as a potential reading audience, but rather as a symbol of innocence, purity, and naivete, which correspond to their concept of the "childhood" of the nation" [9].
In Weimar Germany, the conservative bourgeois' fairy tales, which "were imitative of the Grimms' tales" [1], were consumed by the public in large quantities, being far more popular than the fairy tales written by the proletarian and left-wing writers [1]. The period researcher of the fairy tale genre Bernd Dolle remarked that more "völkisch" (nationalist) the fairy-tale is, the better it sells [8].

Whereas for Brothers Grimm were children "an incidental reading audience" [9], the right-wing authors of fairy tales in Weimar Germany aimed at children concentratedly, as after the first world war, fairy tale became widely acknowledged by political groups as an instrument for the ideological cultivation of a future adult citizens who will determine Germany's future $[1 ; 8]$. Conservative authors produced didactic, societal norms affirming, or idyllic, social passivity encouraging tales [1], while "völkisch" (nationalist) authors as Hans Friedrich Blunck or Gottwalt Weber managed to endow their tales with patriotism to such an aggressive extent, that its' figures (peasants) displayed "dedication against outside forces threatening the harmony of German society" [1].

Nationalist writers have appropriated and taken out of its historical context of Napoleonic occupation already by itself "not unproblematic" [8] nationalistic model of Brothers Grimm, their German-identity constituting envisioning of a "folktale" and its' "childlike purity" as bearing an idealistic link to the "golden age" of German beginning [8]. For illustration, an infamous, blood and soil" (nationalist) author Hans Friedrich Blunck, whose collection of folktales Märchen von der Niederelbe from 1923 has been a commercial success [11], and who became a president of the "Reich Literary Chamber" after Hitler's seizure of power, resembles Grimm Brothers in his combining of Nordic ("Germanic") and "Christian" motives [11]. Like his predecessors, he too perceives the unity of "Germans" in their common linguistic roots [11] and envisions "folktale" as a mode of relation to the religiously uncorrupted "childhood" of German "nation" [8]. In Blunck's preface to Märchen von der Niederelbe, the "folktale" is implied to entail ontological implications; as a "knowledge of the endlessness" which is of "awakening" potential (as after experiencing folktales, "(..) one does not understand how he daily passed through the earth in inattentiveness" [12]). This "knowledge", as Blunck postulates, stems from the morally and religiously "better" past, as through the folktale, "the man sees all land in its liveliness, what our present time cannot perceive 
anymore, as its faith is now too weak" [12]. Synthetizing the "religious" and "national" elements to idealize the "boundness" of German peasant with the nature, even Blunck's "trees", as a part of nations space, are "praying" in the time of crisis [12].

With Kinder- und Hausmärchen intended by Brothers Grimm as an "educational manual" [10], the nationalist, religious and moral "past-time" relating childlike "simplicity, innocence, and plain purity" of folktales (to use the attributes picked by the Brothers Grimm themselves in their 1819 preface [13]), which according to them contains a "purifying power" [13], correlates with the "clear" (simple) perceiving of the Biblical, dichotomic distinction between the "good" and "evil".

In some of the oral variants of the Little Red Riding Hood, the "good" does not conquer the "evil", but the girl gets eaten by the wolf. In other variants, the girl escapes the wolf by claiming to need to urinate or defecate [7]. Involving erotic, cannibalistic, and scatological elements, the tales' oral variants were not didactic and "purifying", as postulated by the Grimm Brothers, but functioned primarily as an entertainment [7]. In contrast, the Brothers Grimm's through the "childlike purity" filtered narrative substantiates a didactic and moralistic dichotomic distinction between the "good" and "evil": On one side, the Grimm's "wolf", characterized by the hunter as a "sinner" [14], in his attempt "to entice her [the Little Red Riding Hood] from the path" [14] by verbally seducing her to brake her mother's commandment to follow the path to the grandmothers house without interruptions (as wolf allures the Ridding Hood, "you walk gravely along as if you were going to school, while everything else out here in the wood is merry" [14]) resembles a biblical snake in the garden of Eden. On the other side, the Little Red Riding Hood, by giving herself in to temptation, in her curiosity resembles the biblical Eve ([also 7, p. 71]. Her first negative experience with the temptation makes her cautious of future "temptations" (of future wolf encounters), and, as emphasized, ensues her living of an ethically positive life: "But Red-Cap went joyously home, and never did anything to harm anyone" [14].

The "purifying" Christian implications of the tale as a referent to the "nations' childhood" are apparent in the Brothers Grimm's narrative. With a didactive appellation in "folktale" narratives remaining a frequent practice also in Weimar tales, Ringelnatz's subversion of the childlike "purity" on the very platform of a "fairy tale" entails a dialogic moment of his contra-nationalist response.

In opposition to the nation's moral "roots" seeking right-wing authors of Weimar Germany, Ringelnatz has been a highly anti-ideological author who degraded and subverted almost every idealistic construct that reached his sight [15]. His deep and anti-dogmatic religiosity corresponds with his writing of bible-parodies and synthetizing of biblical/sacral motives with the motives of excretion and urination [16]. Also, his poem Wirrsal (1923) exhibits intense disregard for the right-wing (as well as any other) radicalism [16]. After the traumatic experience of the First World War, his criticism of ideology becomes solely centrifugal, postponing no monological "truth" apart from the non-ideological factum of human corporeality [15]. Correspondingly, his response to the omnipresent nationalism within the Weimar Germany is analogous to those of his narrator of an unnamed poem, who listens to "patriotic songs" and starts to urinate to the rhythm of their melodies [16]. Likewise, the German nationalism is an object of ridicule in his famous parodies of patriotic hymns Turngedichte (1922): When being "bitten into a butt by the flea", a dedicated patriot and proud member of the nation (of "Volk") of "athletes and thinkers" should not be discouraged from his path towards the "noble goals" [16].

Though less explicitly than in the abovementioned examples, Ringelnatz's tale too follows in the line of his nationalist pathos and idealism degrading tendency. In opposition to the Grimm's "childishly" immaculate Little Red Riding Hood, his Red-Cap is not only sexualized, but also sexually aware, as the indication of her intercourse with the hunter implies. When we juxtapose this indication with the Brother Grimms' religious theme of Red-Caps' following of the "right path", the original texts' moralistic appellation (the position of the "right" Christian "path" which should be followed) is here confrontationally replaced with the non-ideological and nonmoralizing profane corporal life: Not the Red Riding Hood's awareness of the "temptation", but the sexual intercourse brings her to the "right path": "At any rate he [the hunter] did bring her [the Little Red Riding Hood] to the right path" [3].

Rupturing the "purity" of the parodied referent manifests itself also through the Ringelnatzs' making Red-Cap carry to the grandmother not a food of biblical symbolism, "a piece of cake and a bottle of wine" [14], as in the narrative of Brothers 
Grimm, but an amoral plenty of alcoholic beverages: "three bottles of Spanish wine and two bottles of Scotch and a bottle of Rostock rye and a bottle of Swedish punch and a bottle of schnapps and some more bottles of beer and cake and all kinds of junk (...)" [3].

Whereas for Grimm Brothers fairy tales emerge from an omnipresent "eternal source which covers all living things with dew" [13], and thus the fairy tales "faithfully preserve the same source" despite their transition from place to place [13], Ringelnatz relocates the Little Red Riding Hood from an abstract, spatially nondetermined and therefore idealistically universal time-space of German, national consciousness", into a determinable timespace which is not idealistically "omnipresent" but on the contrary, nonabstract and concrete: The Little Red Riding Hood tells the wolf "the exact address, Schwieger Street thirteen, ground floor", and the narrator speculates that the story "must have taken place in Nikolayev or somewhere in Siberia" [3].

Most importantly, in accordance with the transposition of the Little Red Riding Hood narrative from the idealistic ubiquity into a realistic determinateness, Ringelnatz disrupts Brothers Grimm's morally-appellative and in its childlike dichotomic simplicity idealistic structure: Instead of a "good" Grandmother, Hunter and Little Red Riding Hood figures opposing the "evil" Wolf, all figures are in Ringelnatz's version "imperfect" in their moral passivity and therewith realistically ambiguous: The Hunter possibly sleeps with a Little Red Riding Hood who is "just like most dimwitted girls" [3], while grandmother, in Brothers Grimm's text a help-worthy loving figure, devours here the Little Red Riding Hood in an act of aggression. This most "surprising" moment not only violates fairy-tales' "childish purity" by its' brutality, but also substantiates Ringelnatz's negative stance to the Brothers Grimm's conceptualization of the "childlike purity" as of an object of nationalist cherishment on the performative level of figures' acts: Grandmother swallows the Little Red Riding Hood because she gets "angry" over her "childish" questions: "Grandmother, why do you have such a big mouth?' Now is that the right thing for children to say to a grown-up grandmother? So the old woman became so stark raving mad that she couldn't utter one more word" [3].

\section{CONCLUSION}

The "unchildlike" character of Ringelnatz's parodic fairy tale exceeds its being a commentary on the state of a fairy tale genre in Weimar period. More than that, the tale questions Brothers Grimm in more aspects than just by questioning their folkloristic authenticity. In addition to these two aspects, the parodic tale can also be read as an antinationalist utterance. By eliminating the "childishly pure" dichotomy of "good and evil", the biblical friction between these two opposing forces, as well as by stripping the "fairy tale" of its to the "childhood of the nation" referring moral "innocence", Ringelnatz defies Brothers Grimm's romantic conceptualization of a "fairy tale" as of a national identity constituting relation to the morally-religiously ideal past-time ("a golden age") of nations beginning. This axiological opposition to the Brothers Grimm is motivated by the appropriation of their model by Ringelnatz's nationalist contemporaries as of a neoromantic mean for the advocation of "völkisch" nationalism and of a morally ideal "cultural belonging".

Ringelnatz's anti-utopic demystification of an utopic "fairy tale" corresponds with the disregard for the, fairy tales" articulated by his narrator, who despises them as "lies": "My throat's become completely dry from these stupid, stinking stories, which are only all lies anyway" [3].

This condemnation does not frown only upon the Ringelnatz's nonconventional modification of the Little Red Riding Hood presented by the narrator. All "fairy tales" in general become explicated as "lies", bearing no relationship to the actually lived, non-idealistic historical "reality". This contend for a nationalist conceptualization of the "fairy tale" genre in general sheds light on his incorporation of allusion to the "Sleeping Beauty" as to the other famous Grimms' tale within his text ("[...] "the wolf answered in a disguised voice, 'it's me, Sleeping Beauty'" [3]).

Condemning the understanding of a fairy tale as of a possible source of the self-transcending knowledge represents a direct axiological opposition to such neoromantic nationalist conceptualizations of folktale genre as those of Hans Blunck, who presents the folktale as "a knowledge of the endlessness" [12]. Ringelnatz's deconstruction of the fairy tales' "childish" "purifying power" [13] strikes as particularly wise when seen in the light of the upcoming historical development - in the Nazi Germany, Kinder- und 
Hausmärchen become widely distributed as an authoritative educational material on the nature of the "Nordic Germanic past" [17].

\section{AUTHORS' CONTRIBUTIONS}

Duleba M. - forming of hypothesis, summary and comparative analysis of the preceding scholarly discourse, comparative analysis of the referring text and its referent, interpretation.

\section{REFERENCES}

[1] J. Zipes, Recovering the Utopian Spirit of Fairy Tales and Fables from the Weimar Republic, in: J. Zipes (Ed.), Fairy Tales and Fables from Weimar Days, Palgrave, Cham, 2018, pp. 3-26: p. 23, ibid., ibid., p. 58, p. 10, p. 11.

[2] E. Bloch, The Fairy Tale Moves on Its Own in Time, in: E. Bloch, The Utopian Function of Art and Literature, MIT Press, Cambridge, 1988, pp. 163-166: p. 163,

[3] J. Ringelnatz, Kuttel Daddeldu Tells His Children the Fairy Tale About Little Red Cap, in: J. Zipes (Ed.), Fairy Tales and Fables from Weimar Days, Palgrave, Cham, 2018, pp. 4750: p. 48 , p. 49 , p. 48 , p. 49 , p. 47 , p. 49 , p. 48 , ibid., p. 49, ibid., ibid., p. 48.

[4] W. Pape, Joachim Ringelnatz: Parodie Und Selbstparodie in Leben Und Werk, De Gruyter, 1974. p. 290.

[5] J. Zipes, The Trials and Tribulations of Little Red Riding Hood. Second Edition, Routledge, 1993. p. 51, ibid.

[6] A. Detken, "Die Augen, die so wenig sahn vor lauter Phantasie." Joachim Ringelnatz' Gedichte und Geschichten (nicht nur) für Kinder, in: Joachim Ringelnatz, Text und Kritik v. 148, München, 2000, pp. 67-79: p. 76 , ibid.,

[7] C. Monk, Parody as an Interpretative Response to Grimms' Kinder- Und Hausmärchen, U of Otago, 1998. p. 104, ibid., p. 103 , p. 48 , p. 64 , ibid.

[8] H. Karrenbrock, Märchenkinder Zeitgenossen: Untersuchungen zur Kinderliteratur der Weimarer Republik. M und P, 1995. p. 39 , p. 78 , p. 33 , p. 78 , ibid., ibid.
[9] C. Kamenetsky, The Brothers Grimm: Folktale Style and Romantic Theories, in: Elementary English, v. 51, n. 3, 1974, pp. 379-383: p. 379 , p. 381 , p. 379 , ibid., ibid., p. 381, ibid., p. 379.

[10] J. Zipes, The Brothers Grimm: From Enchanted Forests to the Modern World, Palgrave, 2002. p. 46, p. 58, p. 47,

[11] W. S. Hoerle, Hans Friedrich Blunck: Poet and Nazi Collaborator. 1888-1961, Peter Lang, 2003. p. 57 , p. 110 , p. 112 ,

[12] Blunck F. H, Märchen von der Niederelbe, Diederichs, 1923. pp. 1-2, ibid., p. 94, p. 2.

[13] W. C. Grimm, J. L. Grimm, Kinder und Hausmärchen, Winkler Verlag, 1956, pp. 2937: p. 32, p. 37., p. 31, ibid., p. 37.

[14] W. C. Grimm, J. L. Grimm, Household Tales, Duke Classics, 2012, EBook. p. 70, ibid., p. 71, p. 70,

[15] M. Duleba, On the implication of Mikhail Bakhtin's grotesque body to the scholarly comprehension of Joachim Ringelnatz's prose, in: Tomsk, Aktual'nyje problemy lingvistiki I literaturovedenija, n. 7, v. 21, pp. 420-423. DOI: 10.17223/978-5-94621-901-3-2020-11

[16] J. Ringelnatz, Gessamelte Werke, Anaconda Verlag, 2015. pp. 131; 285; 405; 832, p. 252, p. 154 , p. 98 .

[17] C. Kamenetsky, Folktale and Ideology in the Third Reich, in: The Journal of American Folklore, v. 90, n. 356, 1977, pp. 168-178. DOI: https://doi.org/10.2307/539697, p. 169171. 